\title{
ANALISIS PENGARUH PANJANG PROFIL TERHADAP KEKUATAN HEXAGONAL CASTELLATED BEAM DENGAN METODE ELEMEN HINGGA
}

\author{
Patricia Hutami ${ }^{1}$, Leo S. Tedianto ${ }^{2}$, dan Sunarjo Leman ${ }^{3}$ \\ ${ }^{1}$ Program Studi Sarjana Teknik Sipil, Universitas Tarumanagara, Jl. Letjen S. Parman No.1 Jakarta \\ Patricia.325160012@stu.untar.ac.id \\ ${ }^{2}$ Program Studi Sarjana Teknik Sipil, Universitas Tarumanagara, Jl. Letjen S. Parman No.1 Jakarta \\ leotedi@gmail.com \\ ${ }^{3}$ Program Studi Sarjana Teknik Sipil, Universitas Tarumanagara, Jl. Letjen S. Parman No.1 Jakarta \\ sunarjo.leman@gmail.com
}

Masuk: 17-01-2020, revisi: 06-02-2020, diterima untuk diterbitkan: 07-02-2020

\begin{abstract}
Castellated beam actually was an original IWF beam which is cut by several pattern and welded properly in different part to provide higher profile. There are several factors that impact the strength of castellated beam such as, opening angle, cutting width, profile length, etc. This analysis aims to determine the relationship between profile lengths of castellated beam with the strength that the profile could bear until it fully failed, also observing buckling and failure behaviour on castellated beam using finite element method. This issue is necessary due to the characteristic of steel which easily get buckled. This analysis will be assisted by modelling the castellated beam profile using finite element based program. The profile size is IWF 200x100x5,5x8 which is formed into castellated beam size 300x100x5,5x8 with various lengths such as $4 \mathrm{~m}, 6 \mathrm{~m}, 8 \mathrm{~m}, 10 \mathrm{~m}$, and $12 \mathrm{~m}$. The load applied was concentrated load in the middle of the span, with fixed support on both edges of the beam. The results show that the shorter beam profile provides higher strength, and an extreme buckling phenomenon occurs to the longer beam profile, also the longer beam profile fails due to pre-yielding condition, therefore the failure is caused by geometric fails.
\end{abstract}

Keywords: castellated beam; profile length; buckling; finite element method.

\begin{abstract}
ABSTRAK
Castellated beam merupakan baja IWF biasa yang dipotong sedemikian rupa kemudian disambung kembali di bagian yang berbeda menggunakan las, sehingga dihasilkan tinggi profil lebih tinggi dari IWF orisinilnya tanpa harus menambah material. Terdapat banyak faktor yang memengaruhi kekuatan dari castellated beam, seperti sudut pemotongan, lebar pemotongan, panjang profil, dll. Analisis ini bertujuan untuk mengetahui hubungan antara panjang profil dengan kekuatan yang dapat diterima profil tersebut hingga runtuh serta melihat pola buckling dan kegagalan yang terjadi dengan metode elemen hingga. Hal ini merupakan sesuatu yang penting untuk diperhatikan berkaitan dengan sifat baja yang mudah mengalami tekuk atau buckling. Analisis akan dibantu menggunakan program berbasis elemen hingga. Profil yang digunakan yaitu balok IWF berukuran 200x100x5,5x8 yang dibentuk menjadi castellated beam berukuran 300x100x5,5x8 dengan variasi panjang profil $4 \mathrm{~m}, 6 \mathrm{~m}, 8 \mathrm{~m}$, $10 \mathrm{~m}$, dan $12 \mathrm{~m}$. Beban merupakan beban terpusat di tengah bentang dengan perletakan pada kedua ujung batang berupa jepit. Hasil analisis menunjukkan bahwa baja dengan panjang profil lebih pendek menghasilkan kekuatan yang lebih tinggi, baja dengan panjang profil lebih panjang cenderung mengalami tekuk yang ekstrim, dan baja dengan profil lebih panjang gagal dalam kondisi baja belum mengalami kelelehan, sehingga kegagalan diakibatkan oleh kegagalan geometris.
\end{abstract}

Kata kunci: castellated beam; panjang profil; buckling; metode elemen hingga.

\section{PENDAHULUAN}

Castellated beam atau balok kastela merupakan balok dengan bukaan pada web yang terbuat dari balok wide flange (balok I section) yang dipotong sesuai dengan pola bukaan, di rangkai ulang, dan di las sehingga membentuk pola bukaan tersebut. Pembentukan castellated beam sebenarnya bertujuan untuk menambah tinggi profil dari balok wide flange asli. Tinggi castellated beam dapat mencapai 50\% lebih tinggi daripada balok wide 
Hingga

flange aslinya. Hal ini mengakibatkan section modulus dari castellated beam 2,25 kali lebih besar dari section modulus balok wide flange asli, sehingga castellated beam dapat menahan beban lebih besar tanpa harus mengganti profil wide flange dengan profil yang lebih besar dan lebih mahal. Disamping memiliki kelebihan tersebut, rupanya castellated beam juga memiliki beberapa kelemahan antara lain, terjadi konsentrasi tegangan dekat lubang dan kapasitas geser berkurang (Duggal, 2007). Selain itu, sesuai dengan karakteristik baja, castellated beam juga rawan mengalami tekuk. Dalam perancangan dan perhitungan castellated beam terdapat beberapa spesifikasi desain yang memengaruhi kekuatan dan tegangan yang timbul pada castellated beam antara lain: lebar pemotongan (e), sudut pemotongan (Ø), tinggi pemotongan (ho), tinggi profil (dg), distribusi dan jumlah lubang (n), serta panjang bentang profil. Panjang profil berpengaruh besar terutama dalam menentukan kekuatan castellated beam, jenis buckling yang terjadi, dan pola kegagalan yang dialami castellated beam. Pengaruh panjang profi terhadap kekuatan castellated beam akan ditinjau berdasarkan kuat lentur dan tekuk dari penampang. Pada penelitian ini analisis yang dihasilkan berupa beban maksimal yang dapat ditahan castellated beam dengan variasi panjang profil yang berbeda-beda, jenis buckling yang umum terjadi pada castellated beam, dan pola kegagalan yang terjadi pada castellated beam.

Menurut Demirdjian (1999), terdapat beberapa kegagalan yang harus dicek dalam perencanaan castellated beam, antara lain, Vierendeel or Shear Mechanism, Flexural Mechanism, Lateral Torsional Buckling, Rupture of Welded Joints, Web Post Buckling, Web Post Buckling Due to Compression. Lateral-Torsional-Buckling biasanya terjadi pada bentang panjang yang tidak memiliki sokongan lateral memadai pada flange tekan. Kegagalan ini terjadi karena tegangan tekan pada flange tekan menyebabkan defleksi pada balok, sedangkan tegangan tarik pada flange tarik memberikan tahanan defleksi. Selain mengalami defleksi vertikal, balok juga mengalami defleksi lateral, karena penampang tidak memiliki sokongan lateral, sehingga tegangan tekan pada flange mengakibatkan ketidakstabilan dan timbul defleksi lateral. Ketika balok dibebani, defleksi vertikal dan horizontal terjadi bersamaan akibat tegangan tekan pada flange tekan dan tegangan tarik pada flange tarik yang memberikan tahanan defleksi vertikal. Defleksi horizontal muncul karena penampang berusaha melepaskan tegangan tekan pada flange tekan. Adanya defleksi horizontal mengakibatkan perbedaan tegangan tekan yang terjadi pada flange tekan. Hal ini menyebabkan konsentrasi tegangan tekan pada titik belok defleksi horizontal pada flange tekan sehingga flange tertekuk dan penampang menjadi plastis.

Linear Buckling Analysis atau Eigenvalue Buckling Analysis merupakan analisis modal yang cenderung lebih sederhana dan mudah dilakukan, namun hasilnya terbatas. Linear Buckling Analysis menghasilkan nilai buckling load yang menyebabkan terjadinya buckling dan buckling mode. Buckling mode menampilkan asumsi deformasi struktur akibat buckling dalam beberapa mode, namun tidak meunjukkan hasil eksak displacement maupun tegangan. Jumlah mode yang ditampilkan dapat ditentukan oleh pengguna dengan jumlah maksimal sejumlah degree of freedom struktur tersebut. Pada kebanyakan kasus, hanya mode pertama yang bernilai positif yang terjadi, hal ini dikarenakan mode selanjutnya memiliki nilai yang lebih besar, sehingga tidak sempat tercapai. Buckling mode yang ditampilkan berurutan berdasarkan nilai numerikal. Buckling mode yang bernilai negatif berarti arah beban yang diasumsikan bekerja harus dibalik ke arah yang berlawanan agar buckling terjadi pada struktur. Eigenvalues adalah nilai beban ketika buckling terjadi. Eigenvectors adalah bentuk buckling yang berkaitan dengan eigenvalues. Buckling akan tercapai ketika kekakuan tegangan direduksi oleh beban tekan dari kekakuan elastis sehingga resultan kekakuan struktur turun menjadi nol.

Nonlinear Buckling Analysis merupakan analisis lanjutan dari Linear Buckling Analysis (Eigenvalue Buckling Analysis) dengan menambahkan beban yang diaplikasikan secara bertahap dalam beberapa tahap, tidak seperti analisis linear yang mengaplikasikan beban hanya dalam satu tahap. Setiap penambahan beban (load increment) turut mengubah bentuk struktur dan kekakuan struktur, sehingga kekakuan struktur harus diperbaharui terus menerus dalam tiap increment. Lain halnya dengan linear buckling analysis yang tidak memberikan hasil kuantitatif, nonlinear buckling analysis dapat menghitung nilai tegangan dan displacement. Pada linear buckling analysis tidak terdapat ketidaksempurnaan penampang (imperfections), namun pada nonlinear buckling analysis imperfections diprakarsai oleh ketidaksempurnaan yang disebabkan oleh kesalahan diskritisasi, sehingga membutuhkan model dengan ketidaksempurnaan awal (initial imperfections). Jika tidak adanya imperfections, maka harus diadakan untuk mengatur timbulnya buckling.

Dalam suatu permodelan struktur yang dibebani, struktur akan mengalami buckling ketika buckling load tercapai, kemudian displacement akan berangsur-angsur bertambah pada beban yang hampir konstan, dan peristiwa buckling akan menyebabkan keruntuhan struktural. Dalam permodelan, sumber dari analisis nonlinear dapat berupa ketidaksempurnaan geometris ataupun material leleh (yielding). Analisis nonlinear akibat material atau tegangan leleh biasanya dilakukan dalam keadaan plastis keseluruhan, dimana beban sudah konstan, menuju kehancuran struktur sehingga struktur tidak memiliki kekuatan untuk menahan beban.

Permodelan dalam penelitian ini akan menggunakan metode elemen hingga dengan bantuan program computer berbasis elemen hingga. Dalam penelitian ini terdapat 10 kasus yang akan ditinjau untuk mengetahui pengaruh 
panjang profil terhadap kekuatan castellated beam. Kasus 1 sampai dengan Kasus 5 merupakan IWF Beam ukuran 200 x 100 x 5,5 x 8, sedangkan Kasus 6 sampai dengan Kasus 10 merupakan Castellated Beam ukuran 300 x 100 x 5,5 x 8. Sketsa permodelan kasus tersebut dapat dilihat pada Gambar 1, Gambar 2, Tabel 1, dan Gambar 3.

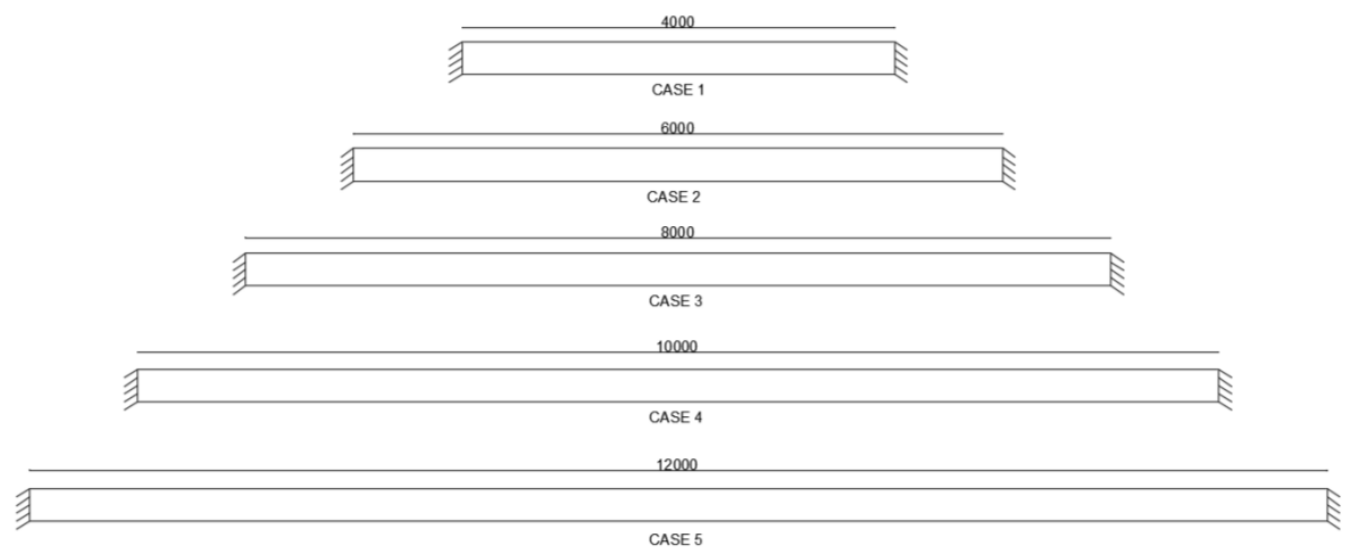

Gambar 1. Sketsa permodelan kasus 1 sampai kasus 5

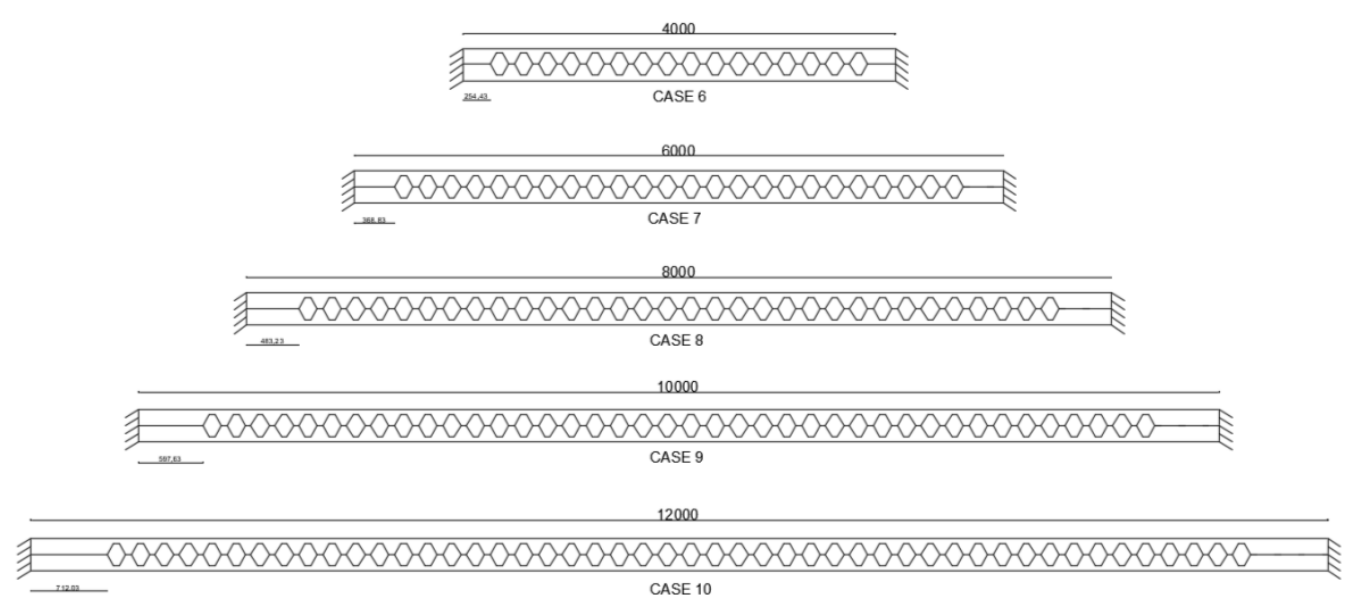

Gambar 2. Sketsa permodelan kasus 6 sampai kasus 10

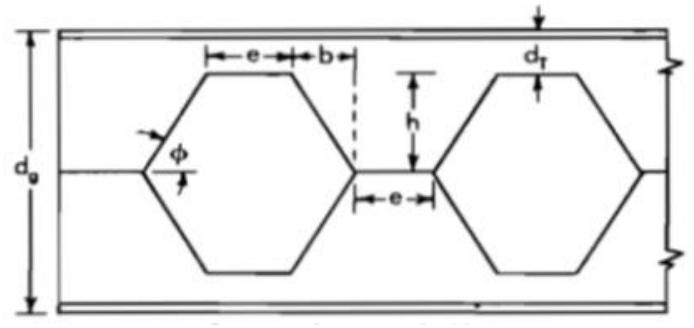

$$
\begin{aligned}
& \mathrm{d}_{\mathrm{g}}=300 \mathrm{~mm} \\
& \mathrm{~d}_{\mathrm{x}}=50 \mathrm{~mm} \\
& \mathrm{~h}=100 \mathrm{~mm}
\end{aligned}
$$$$
\begin{aligned}
& e=51.25 \mathrm{~mm} \\
& \emptyset=60^{\circ} \\
& b=59.45 \mathrm{~mm}
\end{aligned}
$$

Gambar 3. Sketsa spesifikasi lubang 

Hexagonal Castellated Beam dengan Metode Elemen Hingga

Tabel 1. Data permodelan

\begin{tabular}{ccccc}
\hline No & L $(\mathrm{mm})$ & N lubang & Ls $(\mathrm{mm})$ & L/Ls \\
\hline 1 & 4000 & 16 & 254,425 & 0,06 \\
\hline 2 & 6000 & 24 & 368,825 & 0,06 \\
\hline 3 & 8000 & 32 & 483,225 & 0,06 \\
\hline 4 & 10000 & 40 & 597,625 & 0,06 \\
\hline 5 & 12000 & 48 & 712,025 & 0,06 \\
\hline
\end{tabular}

Castellated Beam akan dikerjakan dengan asumsi perletakan pada kedua ujungnya fixed atau jepit yang akan mengunci displacement arah 1, 2, 3 dan putaran sudut arah 1, 2, 3. Pembebanan merupakan beban terpusat di tengah bentang dengan dimensi pelat 10x100 mm. Skema pembebanan dapat dilihat pada Gambar 4 dan Gambar 5 .

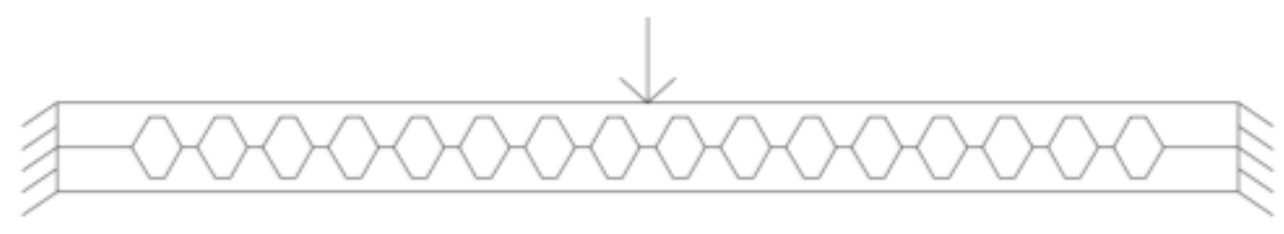

Gambar 4. Tampak samping skema pembebanan

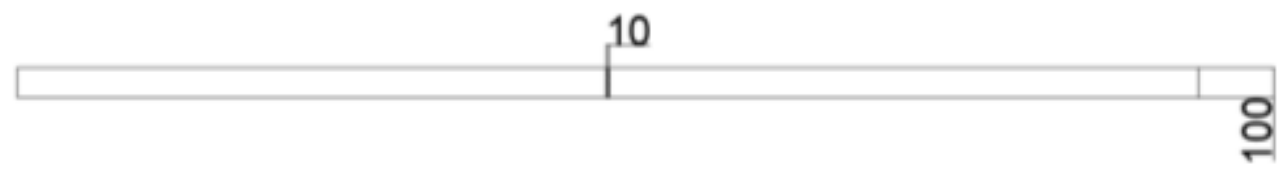

Gambar 5. Tampak atas skema pembebanan

Permodelan material bersifat homogen pada seluruh penampang IWF beam dan castellated beam dengan memperhitungkan berat sendiri profil (density: 7,85 E-09 N/mm ${ }^{3}$ ). Material yang digunakan berupa baja, sehingga Young's modulus diambil $200000 \mathrm{MPa}$ dengan Poisson's ratio 0.3. Mutu material baja yang diambil SS400 dengan nilai yield strength (fy) $245 \mathrm{MPa}$ dan ultimate strength (fu) $400 \mathrm{MPa}$. Pada nonlinear analysis, nilai yield stress yang diambil merupakan true stress dari material SS400 yaitu 245,3001; 365,5926; 493 sedangkan nilai plastic strain yang diambil merupakan true plastic strain dari material SS400 yaitu 0; 0,065246; 0,20658.

Pada penelitian ini digunakan elemen tiga dimensi atau solid berbentuk pentahedron karena lebih tidak sensitif terhadap distorsi. Pemilihan elemen solid dikarenakan elemen solid merupakan permodelan yang lebih realistis, tidak terdapat penyederhanaan geometri, sehingga mesh yang dihasilkan menyerupai objek asli. Di samping memiliki beberapa kelebihan, elemen solid juga memiliki beberapa kekurangan yakni permodelan menjadi lebih kompleks dengan jumlah nodal lebih banyak, sehingga membutuhkan waktu, tenaga, memori komputasi lebih tinggi. Tingkat orde elemen yang digunakan adalah first order element, yaitu berupa elemen linear dimana operasi interpolasi linear dilakukan pada tiap ujung nodal agar diperoleh nilai pada setiap posisi diantara nodal yang ada. Integrasi elemen bersifat full integration element, yakni integrasi elemen yang menggunakan keseluruhan nodal untuk membentuk matriks kekakuan, massa, dan beban. Bentuk meshing yang digunakan adalah wedge, meshing ini memiliki bentuk serupa hexahedron namun berbentuk segitiga. Wedge tidak mudah terdistorsi sehingga menghasilkan permodelan yang lebih baik. Wedge biasanya digunakan pada model dengan adanya bukaan atau model yang memiliki bagian tidak rata. Kesimpulannya, jenis elemen yang digunakan adalah C3D6.

\section{HASIL DAN PEMBAHASAN}

Pada Tabel 2, Tabel 3, dan Gambar 6 akan ditampilkan analisis permodelan IWF beam, sedangkan pada Tabel 4, Tabel 5, dan Gambar 7 akan ditampilkan analisis permodelan castellated beam. 
Tabel 2. Analisis IWF beam

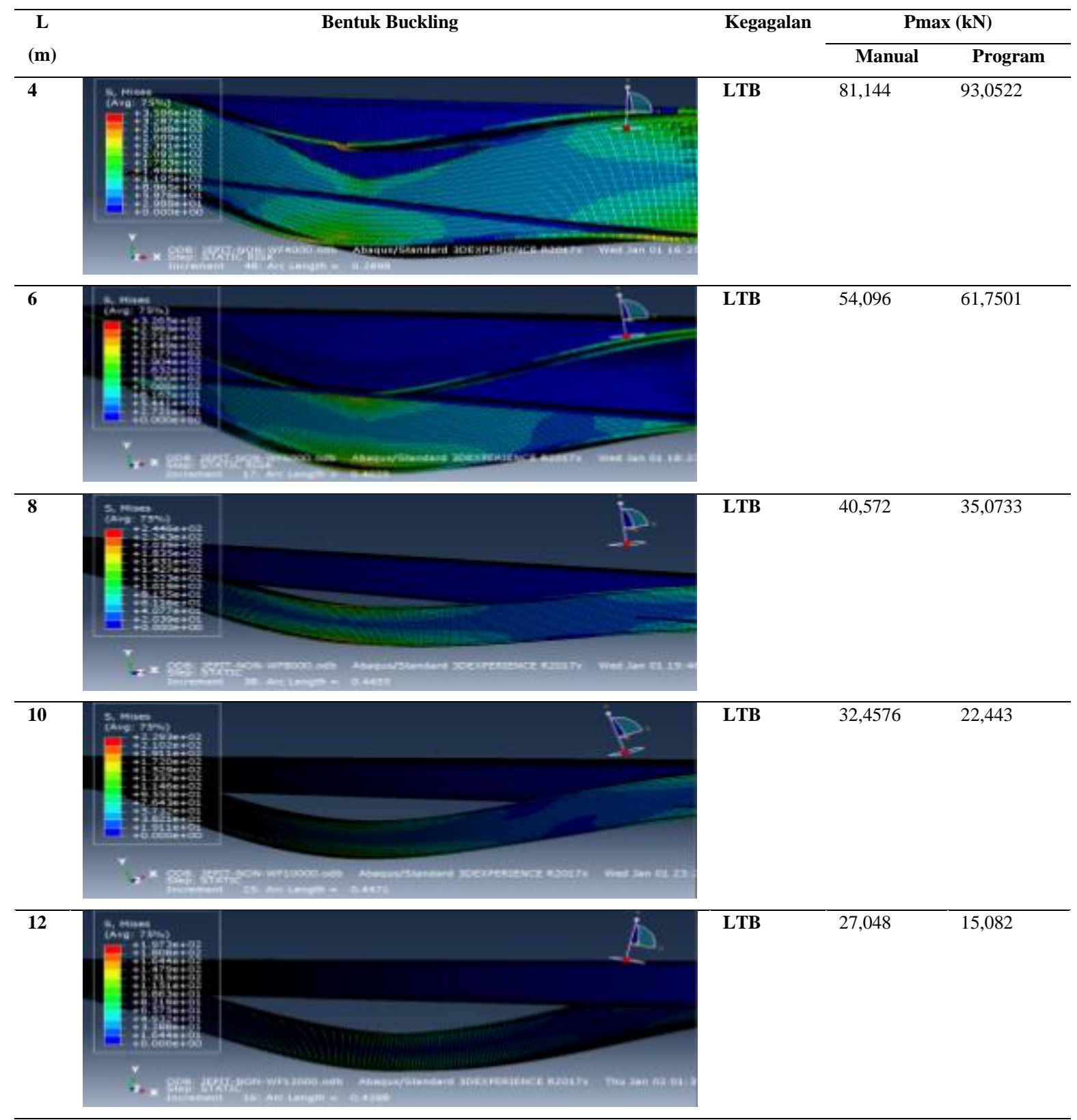

Tabel 3. Beban Maksimal pada IWF Beam

\begin{tabular}{|c|c|c|c|c|c|}
\hline & \multicolumn{2}{|c|}{ P MAKSIMUM (KN) } & \multirow{2}{*}{ SELISIH (\%) } & \multirow{2}{*}{$\begin{array}{l}\text { TEGANGAN } \\
\text { (MPa) }\end{array}$} & \multirow{2}{*}{$\begin{array}{c}\text { MOMEN } \\
\text { PLASTIS TGH } \\
\text { (KNM) }\end{array}$} \\
\hline & PROGRAM & MANUAL & & & \\
\hline WF 4000 & 93,5022 & 81,144 & 15,22996155 & 358,6 & 46,7511 \\
\hline WF 6000 & 61,7501 & 54,096 & 14,14910529 & 326,5 & 46,312575 \\
\hline WF 8000 & 35,0733 & 40,572 & 13,55294292 & 244,6 & 35,0733 \\
\hline WF 10000 & 22,443 & 32,4576 & 30,85440698 & 229,3 & 28,05375 \\
\hline WF 12000 & 15,082 & 27,048 & 44,23986986 & $197, .3$ & 22,623 \\
\hline
\end{tabular}




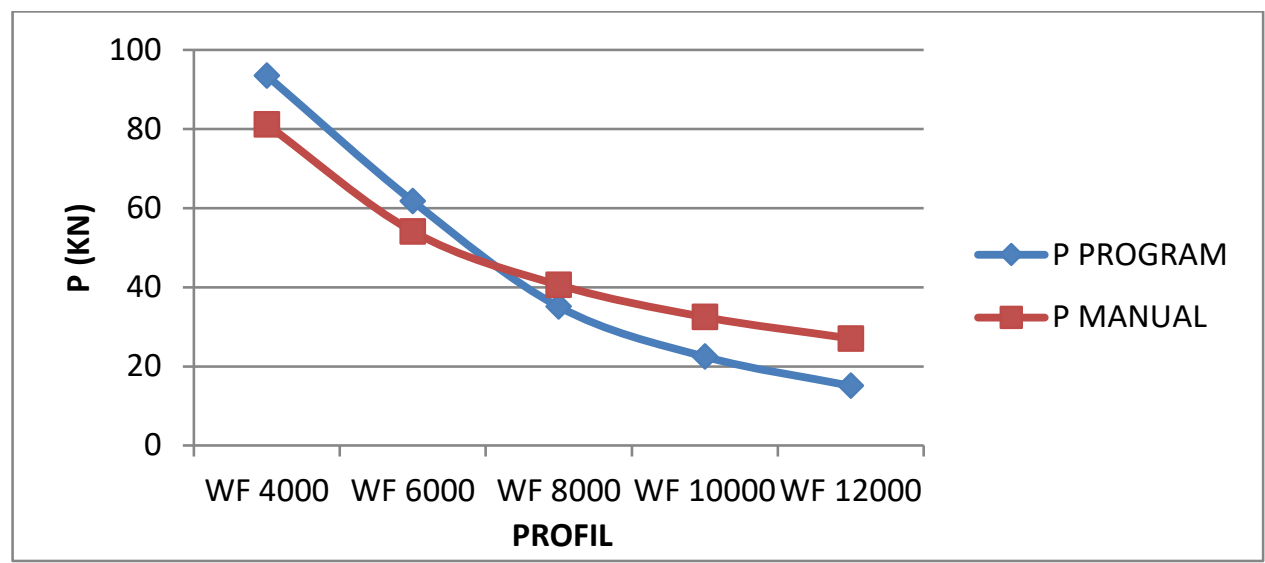

Gambar 6. Grafik perbandingan beban maksimum IWF beam

IWF beam dengan panjang $4 \mathrm{~m}$ dan $6 \mathrm{~m}$ mengalami kegagalan dalam fase near ultimate yaitu ketika true stress pada saat gagal berada diantara 248,675 MPa hingga 365,5926 MPa (WF4000 = 358,6 MPa; WF6000 = 326,5 $\mathrm{MPa}$ ). Hasil penghitungan beban maksimal dengan rumus lebih kecil dibandingkan beban maksimal hasil permodelan dengan program berbasis elemen hingga karena penghitungan manual hanya memperhitungkan sampai kondisi yield (tegangan leleh; fy), sedangkan elemen mengalami kegagalan pada fase setelah yield.

IWF beam dengan panjang $8 \mathrm{~m}, 10 \mathrm{~m}$, dan $12 \mathrm{~m}$ mengalami kegagalan dalam fase yield yaitu ketika true stress pada saat gagal berada diantara 0 hingga 245,3001 MPa (WF $8000=244,6 \mathrm{MPa}$; WF $10000=229,3 \mathrm{MPa}$; WF $12000=197,3 \mathrm{MPa})$. Hal ini menyebabkan hasil penghitungan beban maksimal dengan rumus lebih besar dibandingkan beban maksimal hasil permodelan dengan program berbasis elemen hingga karena penghitungan manual memperhitungkan sampai kondisi yield (tegangan leleh; fy), sedangkan elemen mengalami kegagalan pada fase sebelum yield.

Tabel 4. Hasil analisis castellated beam

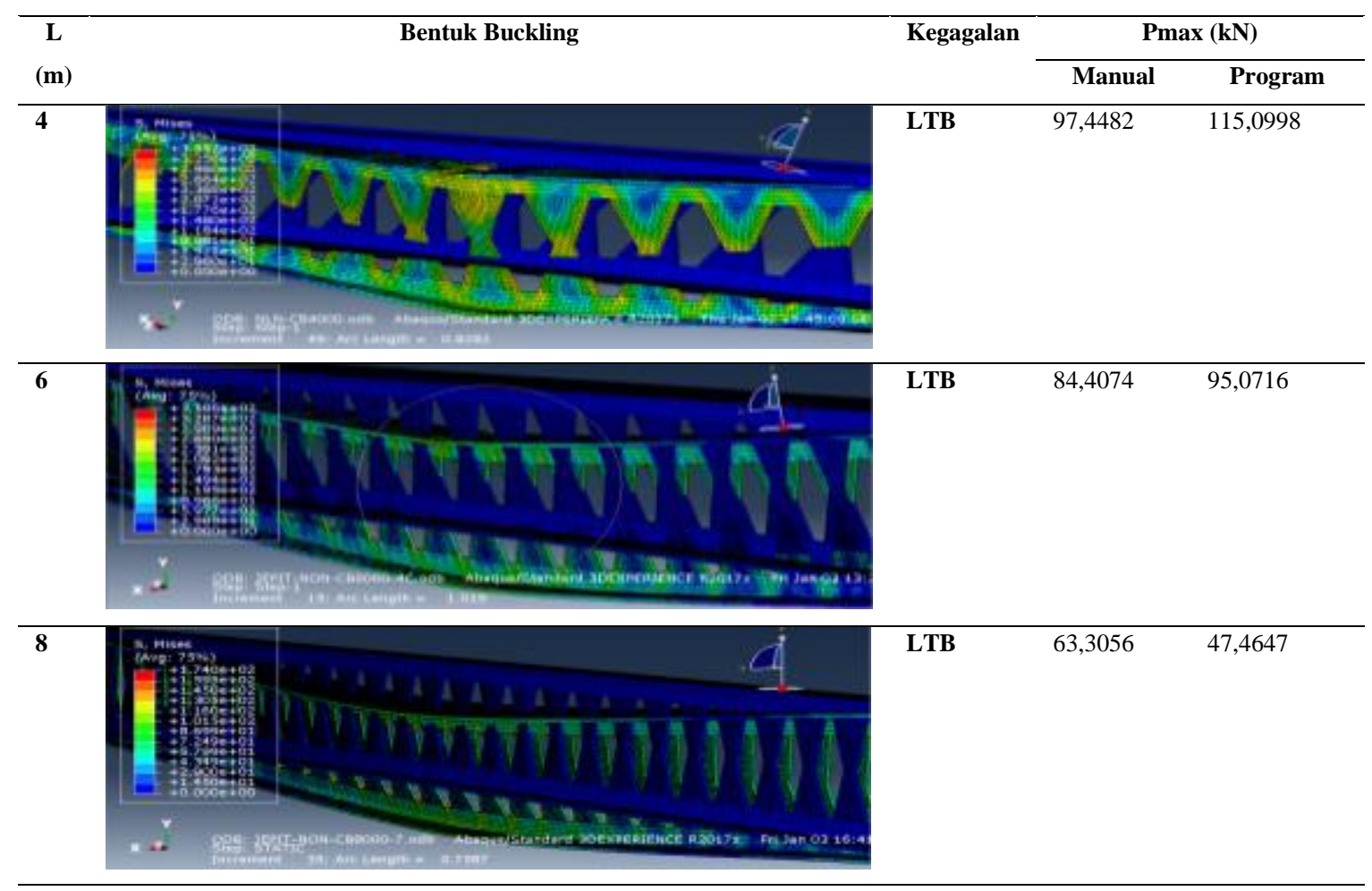


Tabel 4. Hasil analisis castellated beam (Lanjutan)

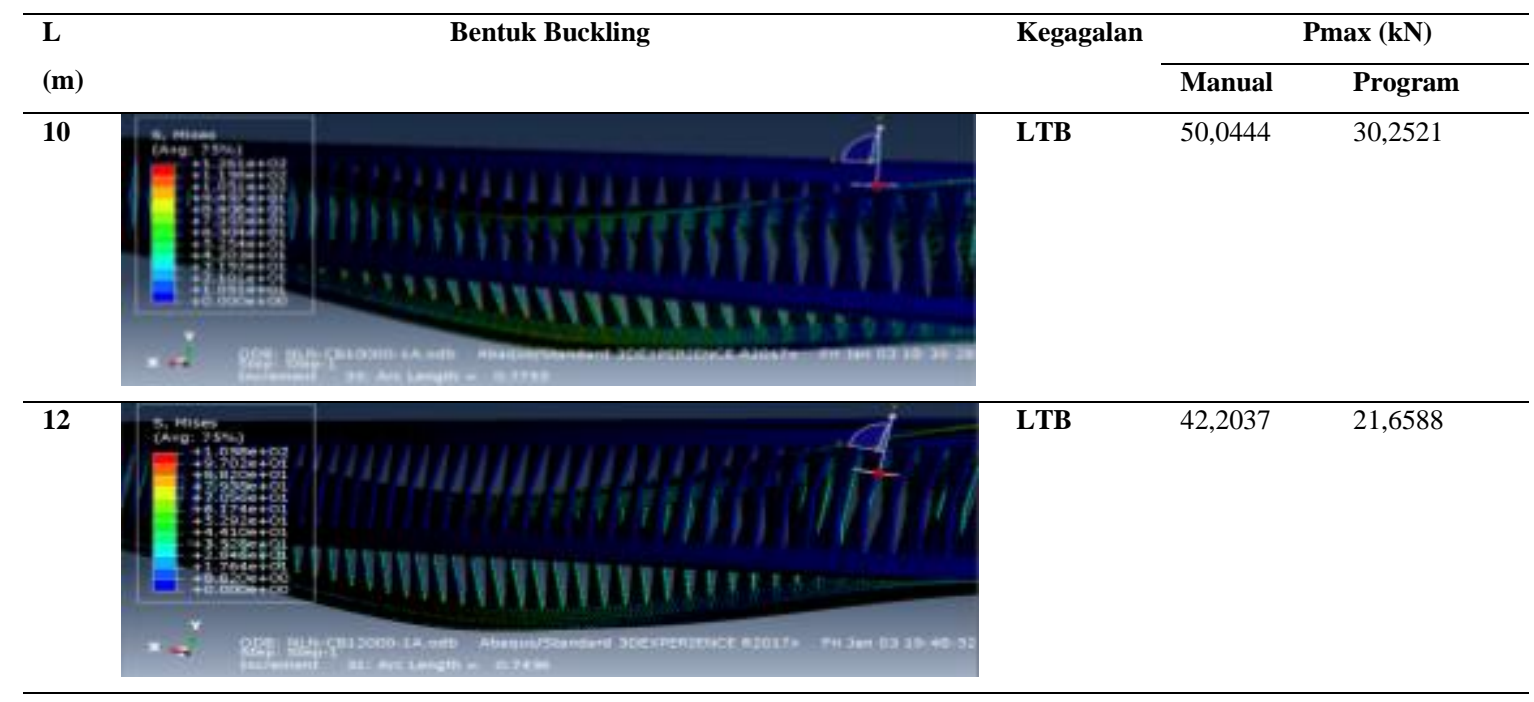

Tabel 5. Beban maksimal pada castellated beam

\begin{tabular}{|c|c|c|c|c|c|}
\hline & \multicolumn{2}{|c|}{ P MAKSIMUM (KN) } & \multirow{2}{*}{ SELISIH (\%) } & \multirow{2}{*}{$\begin{array}{l}\text { TEGANGAN } \\
\text { (MPa) }\end{array}$} & \multirow{2}{*}{$\begin{array}{c}\text { MOMEN } \\
\text { PLASTIS TGH } \\
\text { (KNM) }\end{array}$} \\
\hline & PROGRAM & MANUAL & & & \\
\hline CB 4000 & 115,0998 & 97,4482 & 18,11382868 & 355,2 & 57,5499 \\
\hline CB 6000 & 95,0716 & 84,4074 & 12,63420032 & 358,6 & 71,3037 \\
\hline CB 8000 & 47,4647 & 63,3056 & 25,02290477 & 173,6 & 47,4647 \\
\hline CB 10000 & 30,2521 & 50,0444 & 39,54948006 & 125,6 & 37,815125 \\
\hline CB 12000 & 21,6588 & 42,2037 & 48,68032898 & 104,9 & 32,4882 \\
\hline
\end{tabular}

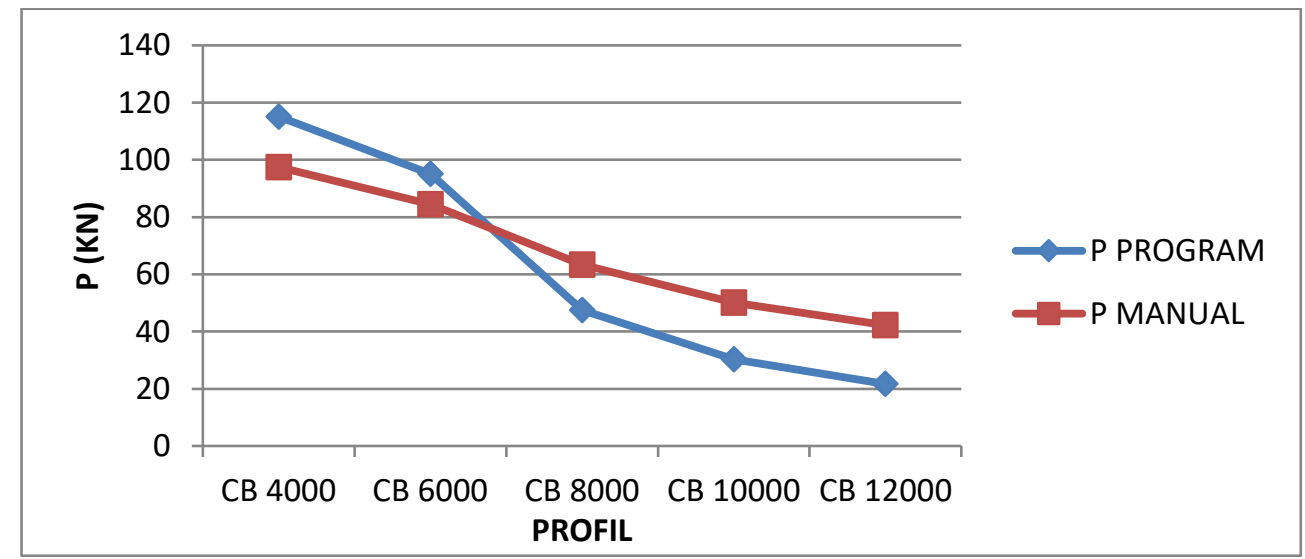

Gambar 7. Grafik perbandingan beban maksimum castellated beam

IWF beam dengan panjang $4 \mathrm{~m}$ dan $6 \mathrm{~m}$ mengalami kegagalan dalam fase near ultimate yaitu ketika true stress pada saat gagal berada diantara 248,675 MPa hingga 365,5926 MPa (WF4000 = 355,2 MPa; WF6000 = 358,6 $\mathrm{MPa}$. Hasil penghitungan beban maksimal dengan rumus lebih kecil dibandingkan beban maksimal hasil permodelan dengan program berbasis elemen hingga karena penghitungan manual hanya memperhitungkan sampai kondisi yield (tegangan leleh; fy), sedangkan elemen mengalami kegagalan pada fase setelah yield.

IWF beam dengan panjang $8 \mathrm{~m}, 10 \mathrm{~m}$, dan $12 \mathrm{~m}$ mengalami kegagalan dalam fase yield yaitu ketika true stress pada saat gagal berada diantara 0 hingga 245,3001 MPa (WF $8000=173,6 \mathrm{MPa}$; WF $10000=125,6 \mathrm{MPa}$; WF $12000=104,9 \mathrm{MPa}$ ). Hal ini menyebabkan hasil penghitungan beban maksimal dengan rumus lebih besar dibandingkan beban maksimal hasil permodelan dengan program berbasis elemen hingga karena penghitungan 
manual memperhitungkan sampai kondisi yield (tegangan leleh; fy), sedangkan elemen mengalami kegagalan pada fase sebelum yield.

Gambar 8 dan Gambar 9 akan menampilkan perbandingan beban maksimum yang dapat ditanggung oleh IWF beam dan castellated beam dengan dua metode yakni perhitungan manual dan analisis menggunakan program berbasis elemen hingga.

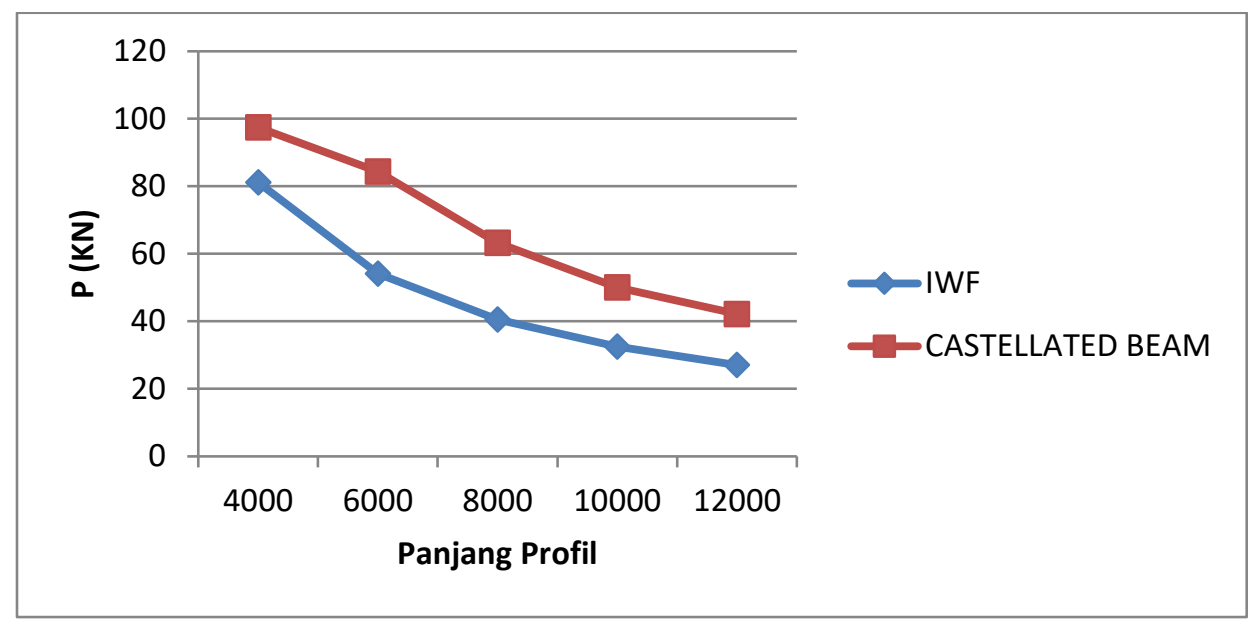

Gambar 8. Grafik perbandingan beban maksimum IWF beam dan

castellated beam (manual)

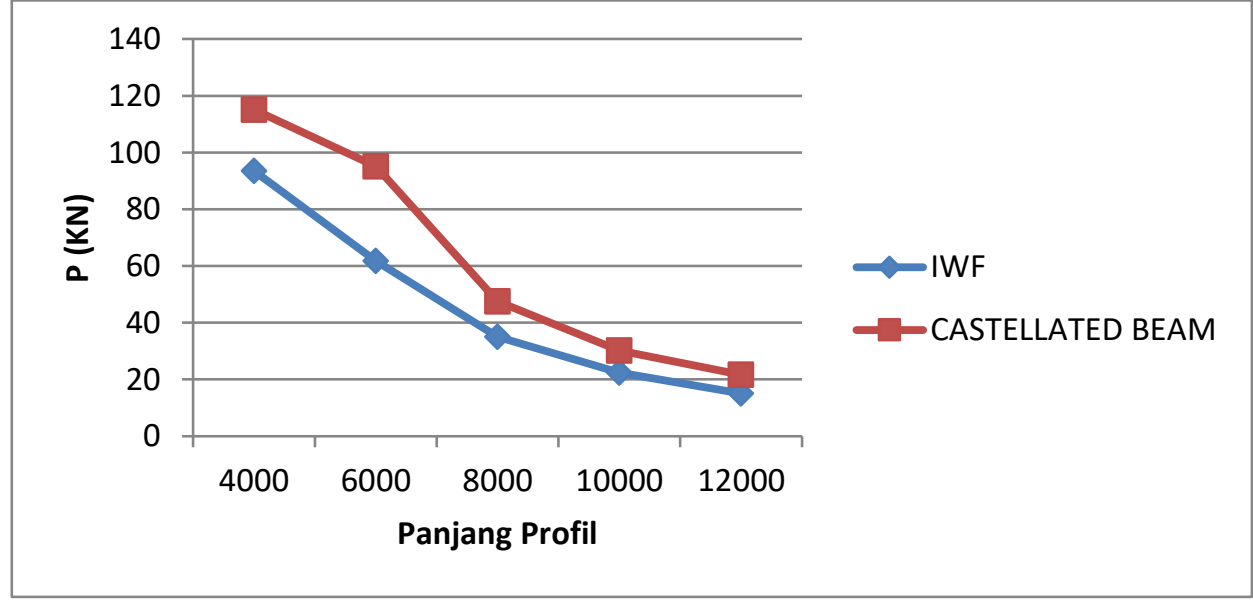

Gambar 9. Grafik perbandingan beban maksimum IWF beam dan

castellated beam (program)

Berdasarkan kedua grafik diatas, castellated beam memiliki ketahanan terhadap beban lebih besar dibandingkan IWF beam, karena castellated beam memiliki tinggi profil lebih besar yang berbanding lurus dengan momen inersia yang lebih besar sehingga menghasilkan kekuatan yang lebih besar pula.

Seluruh model yang dianalisis mengambil perilaku buckling berupa deformed shaped dan nilai eigenvalue dari eigenmode pertama, karena eigenvalue mode selanjutnya lebih besar sehingga eigenmode pertama yang akan terjadi lebih dahulu. Seluruh model mengalami Lateral Torsional Buckling, karena terjadi deformasi lentur pada penampang serta penampang bergeser dari tempat semula. Lateral Torsional Buckling yang dialami seluruh penampang bersifat Elastic LTB ( $\mathrm{Lb}>\mathrm{Lr}=3713,1407 \mathrm{~mm}$ pada IWF beam dan 3198,1893 mm pada castellated beam) sehingga deformasi yang terjadi akibat buckling bersifat sementara dan profil dapat kembali ke bentuk semula. Namun buckling yang terjadi pada IWF beam maupun castellated beam dengan panjang elemen lebih panjang lebih ekstrim jika diamati secara kualitatif dibandingkan dengan IWF beam maupun castellated beam 
dengan panjang elemen lebih pendek. Hal ini dikarenakan elemen yang lebih panjang cenderung lebih tidak kaku sehingga buckling lebih mudah terjadi pada elemen panjang.

\section{KESIMPULAN DAN SARAN}

\section{Kesimpulan}

Berdasarkan hasil analisis yang telah dilakukan dalam penelitian ini, maka dapat disimpulkan bahwa :

1. IWF beam maupun castellated beam dengan panjang elemen lebih pendek memiliki ketahanan terhadap beban lebih tinggi dibandingkan IWF beam maupun castellated beam dengan panjang elemen lebih panjang.

2. IWF beam maupun castellated beam dengan panjang $4 \mathrm{~m}$ dan $6 \mathrm{~m}$ mengalami kegagalan dalam fase near ultimate yaitu ketika true stress pada saat gagal berada diantara 248,675 MPa hingga 365,5926 MPa. Hal ini menyebabkan hasil penghitungan beban maksimal dengan rumus lebih kecil dibandingkan beban maksimal hasil permodelan dengan program berbasis elemen hingga karena penghitungan manual hanya memperhitungkan sampai kondisi yield (tegangan leleh; fy), sedangkan elemen mengalami kegagalan pada fase setelah yield.

3. IWF beam maupun castellated beam dengan panjang $8 \mathrm{~m}, 10 \mathrm{~m}$, dan $12 \mathrm{~m}$ mengalami kegagalan dalam fase yield yaitu ketika true stress pada saat gagal berada diantara 0 hingga 245,3001 MPa. Hal ini menyebabkan hasil penghitungan beban maksimal dengan rumus lebih besar dibandingkan beban maksimal hasil permodelan dengan program berbasis elemen hingga karena penghitungan manual memperhitungkan sampai kondisi yield (tegangan leleh; fy), sedangkan elemen mengalami kegagalan pada fase sebelum yield.

4. Buckling yang terjadi pada IWF beam maupun castellated beam dengan panjang elemen lebih panjang lebih ekstrim jika diamati secara kualitatif dibandingkan dengan IWF beam maupun castellated beam dengan panjang elemen lebih pendek.

5. Buckling yang terjadi pada semua penampang termasuk dalam Lateral Torsional Buckling, karena torsi ekstrim terjadi pada bagian flens atas dan web, sedangkan flens bawah mengalami torsi lebih ringan.

6. Lateral Torsional Buckling yang dialami seluruh penampang bersifat Elastic LTB (Lb > Lr) sehingga deformasi yang terjadi akibat buckling bersifat sementara dan profil dapat kembali ke bentuk semula.

\section{Saran}

Berdasarkan hasil analisis yang telah dilakukan dalam penelitian ini, penulis memberikan beberapa saran sebagai berikut:

1. Pembebanan yang diberikan dapat lebih bervariasi seperti, mengubah beban terpusat menjadi beban merata sepanjang bentang, mengubah dan menambah letak pembebanan, mengkombinasikan pembebanan lentur dan aksial.

2. Perletakan dapat dicoba menggunakan sendi-rol ataupun jepit bebas (kantilever).

\section{DAFTAR PUSTAKA}

Demirdjian, Sevak. Stability of Castellated Beam Webs. Thesis. McGill University. Montreal, 1999.

Duggal, S.K., Design of Steel Structure. New York: The McGraw-Hill Companies, 2010. 
Analisis Pengaruh Panjang Profil terhadap Kekuatan

Patricia Hutami, et.al

Hexagonal Castellated Beam dengan Metode Elemen

Hingga 